\title{
4.1 公宴
}

公子愛敬客

終宴不知疲

清夜游西園

4 飛蓋相追隨

明月澄清景

列宿正參差

秋蘭被長坂

8 朱華冒綠池

潛魚躍清波

好鳥鳴高枝

神風炎接丹暉

12 輕杽隨風移

飄㱠風放志意

千秋長若斯

\section{2 侍太子作}

白日曜青天

時雨靜飛塺

寒冰辟炎景

4 涼風飄我身

Ә Open Access. (C) 2021 Robert Joe Cutter, published by De Gruyter. (c) BY-NC-ND This work is licensed under the Creative Commons Attribution-NonCommercial-NoDerivatives 4.0 License. https://doi.org/10.1515/9781501507038-002 


\section{Shi}

\subsection{Lord's Feast}

The young lord cherishes and respects his guests; ${ }^{1}$

Throughout the feast he does not feel fatigue.

In the pristine night we tour West Garden, ${ }^{2}$

4 Our flying canopies follow each other.

The bright moon bathes us in its pristine rays,

The arrayed constellations now scatter-strewn.

Autumn thoroughwort blankets the long slopes,

8 Vermilion blossoms cover the green pond.

Submerged fish leap in the clear ripples;

Fine birds sing from high boughs.

A prodigious gust catches our cinnabar wheel-hubs,

12 And the light handcarts shift with the wind.

Wafted along we do as we please;

May a thousand autumns always be this way!

\subsection{Seated in Attendance on the Heir Designate}

The white sun glares in the azure sky,

Timely rain settles the flying dust.

Cold ice dispels the scorching sunlight,

4 A cool breeze blows against my body.

1 The "young lord" here is the poet's brother Cao Pi.

2 This was Bronze Bird Garden west of the Wenchang Palace in Ye. 
清酷盈金觞 有穓縱横陳 齊人進奇樂

8 歌者出西秦 翩翩我公子 機巧忽若神

\section{3 元會}

初歲元祚

吉日惟良

乃爲佳會

4 讌此高堂

尊卑列敍

典而有章

衣裳鮮潔

8 料栊玄黄

清酤盈爵

中坐騰光

珍嘻雜遝

12 充溢圆方

笙聲既設

筝瑟俱張

悲歌厲響 
Pure ale fills golden chalices,

Delicacies and choice dishes are arrayed at every turn.

Players from Qi offer wondrous music,

8 The singers come from western Qin. ${ }^{1}$

Graceful is our young lord,

Keen and clever as though divine.

\subsection{New Year's Audience}

The year's beginning commences good fortune,

The auspicious first day is nothing but perfect.

The court holds an elegant gathering,

4 And we feast in this lofty hall.

The high and low sit by rank;

By prescript there are protocols.

Upper and lower garments are fresh and immaculate,

8 Their zigzag and meander motifs are black and yellow.

Clear young ale fills the cups,

The eyes of the feasters sparkle with light.

Rare viands are chockablock,

12 They fill and overflow round and square vessels.

Once pipes and chimes are arranged,

The cithers and zitherns are set up.

The sad songs shrilly resound,

1 Early texts indicate that these states were noted for the quality of their performers.

Their mention here is a form of praise for the banquet and its host. 
16 咀嚼清商

俯視文軒

仰瞻華梁

願保茲喜

20 千載爲常

歡笑盡娱

樂哉未央

皇家第貴

24 嘉考無疆

\section{4 送應氏（其一）}

步登北部坂

遙望洛陽山

洛陽何寂宴

4 宫室盡燒焚

垣牆皆頓擗

荆棘上參天

不見舊者老

8 但覩新少年

側足無行徑

荒壽不復田

遊子久不歸

12 不識陌與阡 
16 We ruminate on the pure shang mode. ${ }^{1}$

Looking down, we see patterned railings,

Looking up, we view ornate rafters.

We want to preserve this joy,

20 For a thousand years to be the norm.

Laughing merrily, we are wholly delighted;

Happy indeed! and not yet finished.

The imperial house is glorious and noble -

24 Long life without end!

\subsection{Seeing off Mr. Ying, No. 1}

Afoot I climb the slopes of Beimang; ${ }^{2}$

Afar I gaze on the hills of Luoyang.

Luoyang - how silent and still!

4 The palaces completely burned down. ${ }^{3}$

Fences and walls all collapsed and broken,

Thorns and brambles reach up to the sky.

I do not see any of the bygone elderly,

8 But only notice the new youths.

I step sideways, for there are no walkways;

The overgrown fields have not been tilled again.

The wanderer has not returned for such a long time

12 He no longer knows the field paths.

1 The shang mode of the pentatonic scale is associated with autumn and sadness.

2 Beimang is the name of the string of low hills north of Luoyang.

3 The destruction and neglect described in the poem are the result of the depredations of Dong Zhuo 董卓 (d. 192), who captured the city in 190 and soon razed it. 
中野何蕭條

千里無人煙

念我平生親

16 氣結不能言

\section{5 送應氏（其二）}

清時難屡得

嘉會不可常

天地無終極

4 人命若朝霜

願得展鞙婉

我友之朔方

親昵並集送

8 置酒此河陽

中饋豈獨薄

賽飲不盡觞

愛至望苦深

12 豈不愧中腸

山川阻且遠

別促會日長

願爲比翼鳥

16 施㬏起高翔 
The countryside - how bleak and desolate!

For a thousand $l i$ no sign of man.

Thinking of those I was close to in life,

16 My breath chokes and I cannot speak.

\subsection{Seeing off Mr. Ying, No. 2}

Idyllic times are hard to come by often;

A happy gathering cannot last forever.

Heaven and earth have no end,

4 But human life is like a morning frost.

I hope I can express my tender affection,

For my friend is going to the northern quarter.

Relatives and friends gather together to see him off,

8 Set out wine here on the river's north bank.

The provisions are by no means meager,

But the guests drink without draining the chalices.

Where love is perfect, hope runs exceedingly deep:

12 How could I not feel ashamed in my innermost being?

The mountains and rivers are rugged and distant;

Parting hastens and our reunion is far off.

I wish that we were linked-wing birds,

16 Spreading our wings to rise and soar aloft. 


\section{6 雜詩}

高臺多悲風 朝日照北林

之子在萬里

4 江湖迥且深 方舟安可極 離思故難任 孤煙飛南遊

8 過庭長哀吟 趐思慕遠人 願欲托遺音 形景忽不見

12 翩翩傷我心

4.7 雜詩（其二）

轉蓬離本根

飄颻隨長風

何意迥颷舉

4 吹我入雲中

高高上無極

天路安可窮

類此遊客子

8 捐軀遠從我 


\subsection{Unclassified Poem, No. 1}

On the high terrace there is much sad wind, The morning sun shines on the northern woods.

That man is a myriad $l i$ away,

4 And the rivers and lakes are distant and deep.

How can my doubleboat reach all the way there?

Feelings of parting are surely hard to bear.

A lone wildgoose flies wandering south;

8 Passing the courtyard, it gives a long mournful cry.

I lift my head, worried, yearning for the one far away;

I wish to ask the wildgoose to convey a message.

But its silhouette suddenly disappears,

12 Its swift flight breaking my heart.

\subsection{Unclassified Poem, No. 2}

The tumbleweed leaves its native roots,

Whirling and swirling in ceaseless winds.

How could I know a whirlwind would rise

4 And blow me into the clouds?

Higher and higher, up without limit;

The road in the sky - how can one reach its end?

Like unto this is the wanderer,

8 Who lays down his life far away in the army. 
毛褐不掩形

微雚常不充

去去莫復道

12 沉憂令人老

\section{8 雜詩（其三）}

西北有織女

綺縞何續紛

明晨秉機杼

4 日旲不成文

太息終長夜

悲嘯入青雲

妾身守空閏

8 良人從軍行

自期三年歸

今已歷九春

飛鳥遶樹翔

12 嗷嘋鳴索帛

願爲南流景

馳光見我君 
Woolens and burlap don't cover his body,

Wild beans and bean leaves often are scarce.

Away, away, I'll say no more!

12 Such deep distress makes men old.

\subsection{Unclassifed Poem, No. 3}

In the northwest is a weaving woman,

Her tabby-weave and undyed silks - how profuse!

At daybreak she takes up the shuttle,

4 But when the sun declines, she has not completed a pattern.

She sighs heavily throughout the long night;

Her sad wailing enters the clouds in the blue.

"I keep to my empty chamber,

8 My good man has gone off to serve in the army.

He expected to return in three years,

Now it has already been nine springs.

A flying bird circles round the tree,

12 Calling dolefully seeking its flock.

I wish I were southward streaming rays,

Speeding like light to see my husband." 


\section{9 雜詩（其四）}

南國有佳人

容華若桃李

朝遊江北岸

4 夕宿潚湘沚

時俗薄朱顔

誰爲發皓齒

俯仰歲將暮

8 第曜難久恃

\subsection{0 雜詩（其五）}

僕夫早嚴駕

吾行將遠遊

遠遊欲何之

4 吴國爲我仇 將駎萬里塗

東路安足由

江介多悲風

8 淮泗馳急流

願欲一輕濟

惜哉無方舟

閒居非吾志

12 甘心赴國憂 


\subsection{Unclassified Poem, No. 4}

In a southern kingdom there is a lady fair,

The beauty of her countenance like peach and plum.

At daybreak she wanders the Yangzi's north bank,

4 In the evening she stays on an islet of the clear Xiang.

The taste of the time disdains a rosy face;

To whom will she reveal her gleaming teeth?

In no time the year draws to an end,

8 Radiant beauty is hard to rely on for long.

\subsection{Unclassified Poem, No. 5}

The driver hitches the carriage early,

I am about to travel afar.

Travel afar but where do I go?

4 The kingdom of Wu is our foe.

I shall gallop a trail of ten thousand $l i$;

The eastern road - how is that worth taking?

Along the Yangzi there is much sad wind,

8 The Huai and Si run with swift currents.

I want to cross easily over at once,

A pity I have no doubleboat.

Staying idly at home is not my ambition,

12 I gladly hasten to respond to the kingdom's troubles. 


\subsection{1 雜詩（其六）}

飛觀百餘尺

臨牊御㰌軒

遠望周千里

4 朝夕見平原

烈士多悲心

小人偷自閒

國倠亮不塞

8 甘心思辳元

撫劍西南望

思欲赴太山

弦急悲聲發

12 聆我慷慨言

\subsection{2 喜雨}

天覆何彌廣

苞育此羣生

棄之必憔悴

4 惠之則滋第

慶雲從北來

㮃秋述西南征 


\subsection{Unclassified Poem, No. 6}

The soaring gate-tower is over a hundred feet high,

I look down from a window, leaning on the latticed railing.

I gaze afar, a thousand $l i$ in all directions,

4 Morning and evening I watch the level plain.

A man of honor is often sad-hearted,

The enemies of the country are clearly unchecked,

While lesser men snatch leisure for themselves.

8 Willingly I intend to give up my head.

I stroke my sword and gaze southwest,

In my mind I want to go to Mount Tai. ${ }^{1}$

When the strings are tight, sad sounds emerge;

12 Hear my impassioned words.

\subsection{Welcome Rain}

Heaven's mantle - how vast and broad!

It enfolds and nourishes all of these living things.

If it abandons them, they must waste and wither;

4 If it favors them, then they grow and flourish.

Felicitous clouds came from the north,

Wreathing upwards and marching towards the southwest.

1 Mount Tai 泰山 is in modern Shandong province in eastern China. It is one of the Five Sacred Mountains 互㑊: Mount Tai in the east; Mount Hua 華山 in the west; Mount Heng 衡山 in the south; Mount Heng 惂山 in the north; and Mount Song 嵩山 in the center. Mount Tai is the holiest of these mountains. The sacrifices Emperor Wu made on Mount Tai in 110 B.C. were mainly to the Yellow Emperor, who was connected in the minds of the time with immortality, but here Cao Zhi is expressing his willingness to die. 
時雨中夜降

8 長雷周我庭

喜種盈膏壤

登秋必有成

\subsection{3 離友（其一）}

鄉人有夏侯威者、小有成人之風、余尚其 爲人、與之昵好。王師振旅、送予於魏 邦、心有漛然、爲之隕涕、乃作離友之 詩。其鿷日、

王旅遊兮背故鄉 彼君子兮篤人綱 媵予行兮歸朔方

4 馳原䇣兮坔舊疆 載車奔兮馬繁㜵 涉浮濟合泛輕航 迄魏都兮息蘭房

8 展宴好兮惟樂康 
Welcome rain fell in the middle of the night,

8 Long peals of thunder encircled the courtyard.

Good seed fills the fertile soil,

In autumn there will surely be a crop.

\subsection{Parting from a Friend, No. 1}

Among the people from my native place is one Xiahou Wei. When he was young, he already had the air of an adult. I admire him as a person and am friendly with him. When the royal army withdrew, he escorted me to Ye. In my heart I did not wish to part from him, and shedding tears over him, I composed the poem "Parting from a Friend." Its words say:

The royal army, returning in triumph, left my hometown behind; ${ }^{1}$

That gentleman, devoted to human relationships,

Came along accompanying me to return to the North.

4 Galloping plains and lowlands, we made our way toward my old haunts;

The carriages raced headlong, the horses ran en masse.

Drifting across the River Ji, we floated on light boats; ${ }^{2}$

Reaching the capital of Wei, we rested in scented rooms, ${ }^{3}$

8 Set out a feast party and were happy and at ease.

1 His "hometown" was Qiao, in modern Bo county, Anhui province. It was not where he was born or where he lived, but it was considered his family's ancestral home.

2 The source of the River Ji was in modern He'nan province. The river ultimately flowed into the Yellow River. The route from Qiao, where Xihou Wei joined Cao Zhi, to Ye would have them cross the Ji on the way north.

3 The capital of Wei was Ye. 


\subsection{4 離友（其二）}

涼風班兮白露滋

木感氣兮條葉辭 臨淥水兮登重基

4 折秋華兮采霝芝

寻水歸兮贈所思

感離隔兮會無期

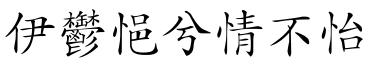

[日匿景兮天微陰

經迴路兮造北林]

\subsection{5 應詔}

㭟承明詔

應會皇都

星陳夙駕

4 秼馬脂車

命彼掌徒

烐我征旅

朝發鸞臺

8 夕宿蘭渚

芒芒原烈 


\subsection{Parting from a Friend, No. 2}

The chilly wind is harsh, white dew spreads;

The trees sense the air, leaves bid farewell to branches.

Looking out over the clear river, I climb a high mountain,

4 Break off autumn flowers, pick numinous mushrooms.

Since he will soon go home afar, I give them to the one I cherish.

I am moved by our parting and separation, no reunion in sight,

I feel depressed, and my mood is somber.

[The sun hides its light and the sky slightly darkens, Passing along the road back, we reach the northern wood.] ${ }^{1}$

\subsection{Responding to an Edict}

I respectfully received your wise edict,

And came in response to attend court in the imperial capital.

Beneath the starry array, I harnessed up early,

4 Fed the horses, greased the carriage.

I ordered the foreman

To alert my military escort.

At dawn I set out from Simurgh Terrace,

8 At dusk I halted at Thoroughwort Holm. ${ }^{2}$

Broad and boundless the plains and fens,

1 The lines in brackets may not be from this poem, and the poem itself is not in all editions of Cao's works. See Additional Notes.

2 These names are not meant to refer to real places, but such names serve two functions: they conjure up the distinctive nature of the emperor's lands; and, along with the dawn-and-dusk formula seen here, they recall the urgent quest for an understanding ruler undertaken by the poet-protagonist of the famous allegorical poem "Li sao" ("Encountering Sorrow"). 
祁祁士女

經彼公田

12 樂我稷㯟

爱有樛木

重陰匪息

雖有餱糧

16 飢不遑食

望城不過

面邑不游

僕夫警策

20 平路是由

玄駟藹藹

揚鏣漂沫

流風翼衡

24 輕雲承蓋

涉澗之濱

綠山之隈

遵彼河滸

28 黄阪是階 
Teeming with men and women.

Passing through those official fields,

12 I rejoiced at our foxtail millet and broomcorn millet.

And there were trees with down-curving branches, But in their dense shade, I did not rest.

Although I had dried rations,

16 Even starving I had no time to eat.

I gazed at towns but did not go through them,

I faced toward cities but paid them no visit.

My driver used the whip,

20 The smooth roads, those we followed.

My team of four black horses was hale and hearty,

They strained at their bits and spewed foam.

The streaming wind buttressed the crossbar,

24 Light clouds held up the canopy.

We crossed over stream banks,

Skirted mountain bends,

Followed along the river's edge,

28 The loess slopes, those we climbed. 
西濟關谷 或降或升 鋋駗倦路

32 載熭載興

將朝聖皇 匪敢晏寧 珥節長珤

36 指日遄征 前驅舉燧 後乘抗権 輪不㪕運

40 鸞無廢聲

爱暨帝室 稅此西墉 嘉詔未賜

44 朝唓莫從

仰瞻城閾 俯惟閭庭 長懷永慕 48 夏心如酲 
Westward we traversed passes and valleys,

Now descending, now ascending.

When the team tired of travel,

32 We slept and rose again and again.

I was going to have an audience with the sage sovereign,

So I dared not be tranquil and calm.

If the pace slowed, we then galloped a long way;

36 Checking the itinerary, we hastened our journey.

The vanguard held torches,

The rear carriages hoisted banners.

The wheels never stopped turning,

40 The carriage bells never ceased ringing.

Reaching the imperial abode,

I stayed by the western wall.

A favorable edict has not yet been bestowed,

44 A court audience I cannot bring about.

Looking up I see threshold of the palace walls, Looking down I contemplate the court.

Ever longing, ever yearning,

48 My worried mind is as though hungover. 


\subsection{6 贈徐幹}

驚風飄白日

忽然歸西山

圓景光未滿

4 眾星燦以繁

志士管世業

小人亦不閒

聊且夜行遊

8 遊彼隻閶間

文昌稂雲興

迎風高中天

春鳵鳴飛橧

12 流宊激櫺軒 顧念蓬室士 貧賤誠足憐 微藿弗充虛

16 皮褐猶不全 慷慨有悲心 興文自成篇 寶棄怨何人 20 和氏有其想 


\subsection{Presented to Xu Gan}

A hard wind whirls away the white sun,

And it suddenly returns to the western hills.

The light of the radiant orb is not yet full, ${ }^{1}$

4 The sundry stars are sparkling and profuse.

The man of ambition strives for achievements for the ages,

Nor is a lesser man like me idle. ${ }^{2}$

For now, I go roaming in the night,

8 And roam between twin gate-towers.

Cultural Splendor rises like a dense cloud,

Windgreeter is as high as mid-sky. ${ }^{3}$

Spring doves coo among the towering ridgepoles,

12 Stray gusts buffet the latticed railing.

I think about that thatched hut scholar,

Poor and humble, truly worthy of pity.

Wild beans and bean leaves do not fill his emptiness,

16 Even his short leather coat is not whole.

Impassioned, he has a sad heart;

Moved to write, he completes his works for himself.

When a gem is rejected, who is to blame?

20 Mr. He made his mistakes. ${ }^{4}$

1 I.e., the moon.

2 The "man of ambition" in line 5 is Xu Gan.

3 The Palace of Cultural Splendor was the principal palace in Ye. Cao Zhi alludes to the Lodge of Greeting the Wind elsewhere in his works, but while the location of Cultural Splendor is indicated on reconstructed maps of Ye, it is not clear where in the city Windgreeter was located.

4 Lines 19-20 draw on the famous story of Bian He 卡和, who presented a piece of raw jade to his king. According to Han Fei zi, when He offered the jade to King Li of Chu, an expert said it was just a rock, and the king had He's left foot cut off. When the king died, He offered the jade to his successor. The jade was again not recognized for its worth, and he lost his right foot. Afterwards, he cried until he wept blood at the foot of the mountains, and when asked why, he replied, "It is not that I am sad because my feet have been amputated. I am sad because a precious jade is labeled a mere rock and a man of integrity is called a cheat." Only after the new, third king heard this was the jade polished and its great value revealed. In the poem, of course, Cao Zhi is likening Xu Gan to the jade and himself to Bian $\mathrm{He}$, who initially failed in getting the jade recognized. 
彈冠俟知已

知已誰不然

良田無晚歲

24 膏澤多䀳年

亮懷眞璠美 積久德愈宣

親交義在敦

28 申章復何言

\subsection{7 贈丁儀}

初秋涼氣發

庭樹微消落

凝霜依玉除

4 清風飄飛閣 朝雲不歸山

霖雨成川澤

㯟稷委儔隴

8 農夫安所獲

在貴多忘賤

為恩誰能博

狐白足禦冬

12 焉念無衣客

思慕延陵子 
To flick the dust from your cap requires a good friend, ${ }^{1}$

Of your good friends, who is any different?

Good fields are not harvested late,

24 Enriching rain brings many bumper crops.

When one truly harbors the beauty of jade,

Over time his virtue stands out more.

A good friend's duty is to encourage;

28 Having presented this poem, what more can I say?

\subsection{Presented to Ding Yí}

Early autumn, cold air arises;

Courtyard trees faintly waste and wither.

Thick frost rests on jade-white steps;

4 Fresh breezes buffet the soaring gallery.

Morning clouds do not return to the mountains;

Incessant rains create rivers and marshes.

Broomcorn and foxtail millet lie abandoned in the fields;

8 How can the farmers harvest anything?

The noble mostly forget the lowly:

In practicing charity, who can do it all?

When your white fox furs suffice to stave off winter,

12 Would you be mindful of strangers lacking clothes?

I think of and admire Yanlingzi,

1 Flicking the dust from one's cap is a metaphor for taking up an official position. 
寶劍非所惜 子其寧雨心

16 親交義不薄

\subsection{8 贈王粲}

端坐苦愁思

攬衣起西遊

樹木發春華

4 清池激長流 中有孤鴐䴇

哀鳴求匹儔 我願執此鳥

8 惜哉無輕舟 欲歸忘古道 顧望但懷愁 悲風鳴我側

12 羲和逝不留 重陰潤萬物 何濯澤不周 誰令君多念 16 自使惇百憂 
Ungrudging of his precious sword. ${ }^{1}$

You may set your mind at rest:

16 Your close friend's loyalty is undiminished.

\subsection{Presented to Wang Can}

Sitting erect, I am troubled by sorrowful thoughts,

Gathering up my robe, I rise and wander west. ${ }^{2}$

The trees put forth their spring blossoms,

4 The clear pond stirs a steady current. ${ }^{3}$

In the middle is a lone mandarin duck

Mournfully calling in search of its mate.

I want to befriend this bird,

8 A pity I have no light craft!

I wish to go back but have forgotten the way I came;

When I look back, I feel only sorrow.

A sad wind soughs by my side,

12 Xihe goes and will not stay. ${ }^{4}$

But the layered clouds moisten all things:

Why fear their favor will not extend all around?

Who causes you to brood so much?

16 You make yourself harbor these hundredfold worries.

1 Yanlingzi is a name referring to Ji Zha 季札, who lived in the sixth century BCE and was the youngest son of the King of Wu. Accounts say that when Ji Zha passed through the state of $\mathrm{Xu}$, the ruler of $\mathrm{Xu}$ greatly desired the precious sword that Ji Zha wore but didn't say anything. Ji Zha could see what was on the $\mathrm{Xu}$ ruler's mind but could not offer him the sword, because he was traveling as an envoy to the major state of Jin. He planned to give the sword to the Xu ruler on his way back. But by then the Xu ruler had died, so Ji Zha hung the sword on a tree in front of the Xu ruler's grave, then left. Because of this, there was a song in $\mathrm{Xu}$ that said, "Yanling Jizi did not forget old friends, / He took off a sword worth a thousand in gold and strung it by the tomb."

2 This is usually understood to mean that he goes to visit Ye's Western Garden.

3 This is probably a reference to the Xuanwu Reservoir in the Western Garden.

4 Xihe was the charioteer of the sun. 


\subsection{9 贈丁儀王粲}

從軍度函谷

驅馬過西京

山岑高無極

4 㴧渭揚濁清

奘哉帝王居

佳麗殊百城

員關出浮雲

8 承露晒泰清

皇佐揚天惠

四海無交兵

權家雖愛勝

12 全國為令名

君子在末位

不能歌德聲

丁生怨在朝

16 王子歡自管

歡怨非貞則

中和誠可經 


\subsection{Presented to Ding Yí and Wang Can}

Accompanying the army, we crossed Hangu;

Spurring our horses, we passed the western capital. ${ }^{1}$

Mountains and peaks were infinitely high;

4 The Jing and the Wei shown turbid and clear. ${ }^{2}$

O magnificent! this home of emperors and kings!

Its fine beauty exceeds a hundred cities.

The Round Gate-towers emerge from drifting clouds,

8 Dew collectors scrape Grand Clarity. ${ }^{3}$

The imperial assistant spreads celestial favor, ${ }^{4}$

And within the four seas there is no clash of arms.

Although a military tactician loves victory,

12 Taking a state in one piece makes a good name.

You are in low-ranking positions

And cannot extol his virtuous reputation.

Mr. Ding is resentful at court,

16 Master Wang is elated to make his own plans.

But elation and resentment are not the right standards;

Moderation and harmony truly can serve as a guide.

1 Hangu was the name applied in Han times to a strategic pass northeast of modern Tiemen county 鐵門縣, He'nan province. "Western capital" refers to the old Han capital at Chang'an.

2 Of the two rivers, the Jing runs muddy, and the Wei is clear.

3 "Grand Clarity" can be understood here simply to mean "high heaven." "Round Gate-towers" and the dew collectors both refer to structures built during the reign of Emperor Wu of Han (r. 140-87 BCE) at the Jianzhang Palace in Chang'an. The twin pylons of the Round Gate-towers were capped with bronze phoenixes and were said to be over one hundred fifty feet high. The dew collector was held aloft by a statue of an immortal atop a pillar. A pan held by the immortal, which contained a cup for collecting dew, was said to be over two hundred feet in diameter.

4 The "imperial assistant" is Cao Cao. 


\subsection{0 贈白馬王虎}

黄初四年五月, 白馬王、任城王與餘俱朝 京師, 會節氣。到洛陽, 任城王薨。至七 月, 與白馬王還國。後有司以二王歸藩, 道路宜異宿止, 意毒恨之! 蓋以大別在數 日, 是用自剖, 與王辭焉, 愤而成篇。

謁帝承明盧 逝將歸舊疆 清晨發皇邑

4 日夕過首陽 伊洛廣且深 欲濟川無梁 汎舟越洪濤

8 怨彼東路長 顧瞻戀城關 引領情內傷

其二

大谷何胗廓

12 山樹鬱蒼蒼 霜雨泥我途 流潦浩從横 


\subsection{Presented to Biao, Prince of Baima}

In the fifth month of Huangchu 4 [223], the Princes of Baima and Rencheng and I all went to attend court at the capital and gather for [the ritual of welcoming] the solar term. ${ }^{1}$ After we arrived in Luoyang, the Prince of Rencheng died. When it got to be the seventh month, the Prince of Baima and I were going to return to our princedoms together. But later someone in charge thought that we two princes returning to our fiefdoms should en route separately stop for the night, and in my mind, I deplored and resented it. Because our big parting was likely to be in a few days, I used these poems to unburden myself and bid farewell to the Prince with them. I wrote the poems out of anger.

I paid my respects to the emperor at Chengming Lodge,

And am about to return to my old realm. ${ }^{2}$

In the clear dawn, I set out from the imperial city,

4 At sunset I pass Mount Shouyang.

The Yi and the Luo are wide and deep,

I want to cross them but there's no bridge.

Going by boat, I pass over huge waves,

8 Complain that road east is long.

Looking back, I long for the gate-towers of the capital;

Craning my neck, my emotions are painful within.

II.

Grand Valley - how vast and empty!

12 The trees on its hillsides a mass of grey-green.

Incessant rain muddies my road,

And the runoff overflows all around.

1 Cao Biao (195-251) was Cao Zhi's younger half-brother. The Prince of Rencheng was Cao Zhi's elder brother Cao Zhang (d. 223). Welcoming the solar term (or seasonal ether) was a Han observance that was continued under the Wei. That year the Autumn's Beginning was on the twenty-fourth day of the sixth month (August 8, 223)

2 At the time, Cao Zhi was Marquis of Juancheng 㖶城. 
中逵絕無軌

16 改轍登高崗 脩阪造雲日 我馬玄以黄

其三

玄黄猶能進

20 我思㯱以紆 稂紆將何念 親愛在離居 本圖相與偕

24 中更不克俱 鴟臬鳴衡軛 娐狼當路嘚 荅蠅間白黑

28 桷巧令親疏 欲還絕無蹊 攬彎止踟䠣

其四 踟踮亦何留

32 相思無終極 秋風發微涼 
Crossroads are cut off and the track is gone,

16 So I change my route and climb a high ridge.

Its long slope reaches as far as the clouds and sun, And my horses are dark and sallow. ${ }^{1}$

III.

Dark and sallow yet they still can go on,

20 But my thoughts are tangled with gloom.

Tangled with gloom - what is troubling me?

We loved ones are to stop in separate lodgings.

We originally planned to be alongside each other,

24 But things changed midway - we could not be together:

Owls hooted on the crossbar and yoke,

Dholes and wolves blocked the roads and thoroughfares, ${ }^{2}$

Blue flies debased black and white,

28 Slanderers and flatterers caused relatives to be estranged.

I want to go back but am cut off without a path;

Pulling the reins, I stop and hesitate.

IV.

Hesitate, but why tarry?

32 My longing for you has no end.

The autumn wind brings a slight chill,

1 This is an allusion to the Classic of Poetry: "I ascend that high ridge, / My horses are dark and sallow." The traditional interpretation is that "dark and sallow" means the dark (i.e., black) horses have turned sallow due to being afflicted with fatigue.

2 The owls and the dholes and wolves, like the flies in the next line, are metaphors for those who were hostile to Cao Zhi and spoke ill of him. 
寒蟬鳴我側 原野何蕭條

36 白日忽西匿 歸鳥赴喬林 翩翩庽羽翼 孤獸走索群 40 御草不遑食 感物傷我懷 撫心長太息

其五

太息將何為

44 天命與我違 奈何念同生 一往形不歸 孤魂翔故域

48 靈殹寄京師 存者忽復過 亡攻身自衰 人生處一世

52 去若朝露晞 年在桑榆間 影響不能追 
Cold cicadas chirr by my side.

How desolate the countryside!

36 The white sun suddenly hides in the west.

A returning bird heads for the tall woods,

Darting along, swiftly flapping its wings.

A lone beast scurries seeking its herd,

40 No time to eat the grass in its mouth.

Being moved by these things wounds me to the core;

Putting hand to heart, I heave a long sigh.

V.

Heave a long sigh, but for what?

44 Heaven's fate is against me.

Why dwell on my full brother?

Once gone a body does not return.

His lone soul soars to his old realm,

48 While his coffined remains stay on in the capital.

We survivors will quickly pass away as well;

Departed, the body naturally dissolves.

A human life inhabits just one age;

52 It goes like morning dew drying in the sun.

My years are at the time of mulberry and elm, ${ }^{1}$

Light and sound cannot keep pace.

1 "Mulberry and elm" signify evening or lateness in life. Two explanations for this usage exist. One is that the setting sun shines on the tops of the mulberry and elm trees. The other is that Mulberry and Elm were the names of two asterisms in the western sky between which the sun set. 
自顧非金石

56 咄唶令心悲

其六

心悲動我神

棄置莫復陳

丈夫志四海

60 萬里猶比鄰

恩愛苟不虧

在遠分日親

何必同衾幬

64 然後展殷勤

夏思成疾疹

無乃兒女仁

含卒骨肉情

68 能不懷苦辛

其七

苦辛何虑思

天命信可疑

虛無求列仙

72 松子久吾欺

變故在須舁 
As I look on myself, neither metal nor stone,

56 In a gasp it makes my heart sad.

VI.

My heart being sad disturbs my spirit;

I'll dispense with this and tell no more.

A true man sets his mind on the world at large,

60 A myriad $l i$ is like his next-door neighbor.

If our loving affection does not diminish,

Though far apart our affection will daily grow closer.

What need to share a quilt and bedcurtains

64 Before extending earnest regard?

If anxious thoughts were to turn into illness,

Would not that be an adolescent infatuation?

Of a sudden such feelings of flesh and blood,

68 Can I not harbor bitter anguish?

VII.

In bitter anguish, what do I brood over?

Heaven's fate is truly untrustworthy.

Absurd to seek the various immortals,

72 Master Pine has long deceived us. ${ }^{1}$

Catastrophe lies a moment away,

1 This refers to the legendary immortal Master Red Pine. 
百年誰能持 離別永無會

76 執手將何時 王其愛玉體 俱享黄髮期 收淚即長路

80 援筆從此䲞

\subsection{1 贈丁廝}

嘉賓填城關 豊羘出中廚 吾與二三子

4 曲宴此城隅 秦箏發西氣 齊瑟揚東謳 有來不虛歸

8 觞至反無餘 我豈狎異人 朋友與我俱 大國多良材

12 譬海出明珠 君子義休侍 小人德無儲 
Who can last a hundred years?

Once parted, we shan't meet for an eternity,

76 When are we ever going to clasp hands?

May you take care of your precious self

And both of us enjoy days of grizzled hair.

Stemming my tears, drawing near the long road,

80 I take up my brush and bid henceforth farewell.

\subsection{Presented to Ding Yi}

Fine guests fill the town,

Choice viands emerge from the central kitchen.

But I and a few others,

4 Feast privately in a nook of the city-wall.

A Qin cither sends forth a western air,

A Qi zithern performs an eastern song.

Delicacies come and don't go back for nothing;

8 Chalices arrive and return without a drop.

Why would I mingle with strangers?

Intimate friends are together with me.

Our great state has many talented men,

12 Just as the sea produces bright pearls.

A gentleman's decency is perfect and amply cached;

Lesser men have no reserves of virtue. 
積善有餘度

16 榮枯立可須 滔蕩固大節 世俗多所拘 君子通大道

20 無願為世儒

\subsection{2 朔風}

仰彼朔風

用懷魏都

願騁代馬

4 修忽北徂

凱風永至

思彼蠻方

願隨越鳥

8 翻飛南翔

四氣代謝

懸景運周

別如俯仰

12 脫若三秋

昔我初遷

朱華未希 
Amassing good deeds brings a surfeit of blessings,

16 Through ups and downs one can stand by and wait.

Magnanimously hold to what's most important -

Ordinary people are too bound by convention.

The gentleman comprehends the Great Way,

20 And has no desire to be an ordinary scholar. ${ }^{1}$

\subsection{Boreal Wind}

I lift my face to that boreal wind,

And, so, long for Wei's capital.

I yearn to gallop a horse from $\mathrm{Dai}^{2}$

4 And swiftly and speedily head north.

When balmy winds come from afar,

I long for that Man region, ${ }^{3}$

Yearn to follow a bird from Yue

8 And flittering and flying soar to the south.

The four seasons wane in turn,

And the suspended luminaries move in cycles. ${ }^{4}$

Parting was as sudden as a glance up and down,

12 But our separation has been like three autumns.

Back then when I was first transferred,

Vermilion blossoms were not yet scarce,

1 The term "ordinary scholar" is notably used by Wang Chong, who considers the work of those who compose their own works, or "literary scholars" 文儒, superior to that of ordinary scholars (common pedants), who discourse on the classics and sages.

2 Dai commandery was in the north of modern Shanxi province and was noted for producing good horses.

3 "Man region" means the South.

4 The sun and moon. 


\section{今我旋止}

16 素雪云飛

俯降千灱

仰登天阻

風飄蓬飛

20 載離寒暑

千仞易陟

天阻可越

昔我同袍

24 今永靟別

子好芳草

豈忘爾貽

繁華將茂

28 秋霜悴之

君不垂眷

豈云其誠

秋蘭可喻

32 桂樹冬第

絃歌蕩思

誰與銷愁 
Now as I return,

16 White snow flies.

Downward descending a thousand fathoms,

Upward ascending a sky-high fastness,

Tossed by wind the tumbleweed flies,

20 Successively encountering cold and heat.

A thousand fathoms are easily climbed,

A sky-high fastness can be got over,

But from my close companions of former days,

24 Now forever parted.

You were fond of fragrant plants.

Would I forget to gift you some?

But just as the riotous blooms were about to peak,

28 Autumn frost withered them.

Though milord no more grants me kind concern,

How could I go back on my loyalty to him?

Autumn thoroughwort may serve as a metaphor,

32 Or the cinnamon tree's flowering in winter.

Singing to strings washes worry away,

But who will dispel sorrow with me? 
臨川慕思

36 何為泛舟

豈無和樂

游非我憐

誰忘汎舟

40 愧無榜人

\subsection{3 矯志}

芳桂雖香 難以飭魚 尸位素餐

4 難以成居

磁石引鐵

於金不連

大朝舉士

8 愚不聞焉

抱璧途乞

無為貴寶

履仁遘禍

12 無為貴道 
By the river, I pine and long -

36 Who will ply a boat for me?

Is there really no one to harmonize with?

My companions are not those I love.

Who would not think to take a boat?

40 I am ashamed I have no boatman.

\subsection{Resolve}

Sweet the smell of fragrant cassia,

But it's hard to bait a fish with it;

In a sinecure with unearned pay,

4 It's hard to establish a permanent household.

Lodestone attracts iron

But doesn't fasten to bronze;

Great courts appoint gentlemen,

8 But dullards are not known therein.

If holding a jade disc one begs by the road, It will not be considered a valued treasure; If by being humane one encounters disaster,

12 It will not be seen as a valued path. 
鴐雛遠害

不羞卑棲

霝虬避鞓

16 不恥污泥

都蔗雖甘

杖之必折

巧言雖美

20 用之必滅
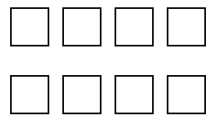

濟濟唐朝

24 萬邦作孚

逢蒙雖巧

必得良弓

賢主雖智

28 必得英雄

螗螂見嘆

率士輕戰

越王軾蛙

32 國以死獻 
The yuanchu-bird keeps far from harm,

It's not ashamed of humble roosts.

The numinous spirax avoids trouble,

16 It's not embarrassed by filthy mud.

Sugar cane may be sweet,

But a staff of it will surely break;

Glib words may be pretty,

20 But following them must lead to ruin.

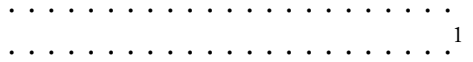

Imposing was the court of Tang, ${ }^{2}$

24 The myriad states trusted it.

Though Pengmeng was skilled,

He had to obtain a good bow. ${ }^{3}$

Though a sage ruler be wise,

28 He has to obtain outstanding men.

A mantis was praised,

And the soldiers of Qi looked lightly on war. ${ }^{4}$

The King of Yue bowed to a frog from his chariot,

32 And men offered their lives for the state. ${ }^{5}$

1 The rhyme scheme in Chinese shows that there must be at least two lines missing.

2 Tang is the legendary sage ruler Yao.

3 Pengmeng was a protégé of the mythical archer Yi 㑭.

4 An anecdote says that Duke Zhuang of Qi 齊莊公 (r. 553-548 BCE) was out hunting when a praying mantis tried to grab the wheel of his chariot. He praised its bravery and backed up the chariot so as not to harm it. As a result, brave men flocked to his service.

5 A similar anecdote says that Goujian stood at his chariot's grab-bar and bowed to an angry frog in order to inspire a spirit of sacrifice in his soldiers for a coming battle with the state of Wu. 
道遠知㨫

世偽知賢
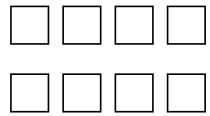

覆之㡐之

順天之矩

澤如凱風

40 惠如時雨

口為禁䦬

舌為發機

門機之闘

44 楛矢不追

\subsection{4 閨情}

攬衣出中閨

逍遙步兩楹

閒房何寂胗

4 綠草被階庭

空穴自生風

百鳥翩南征

春思安可忘 
If the road is long, know your steed;

If the age is fraudulent, know the worthy.

Overspreading, overlaying, ${ }^{2}$

Follow Heaven's norms.

Let favor be like a balmy wind,

40 Beneficence like a timely rain.

The mouth is a palace door,

The tongue is a crossbow trigger.

Once door and trigger are pulled open,

44 The thornwood arrow cannot be recalled.

\subsection{Boudoir Feelings, No. 1}

Gathering up my robe, I leave the inner apartments, Wander between two pillars.

The vacant rooms, how silent and still!

4 Green grass blankets steps and courtyard.

Spaces and gaps naturally bring on a breeze, All the birds soar migrating south.

Spring thoughts, how can they be forgotten?

1 There must be at least two lines missing here. See Additional Notes.

2 This line alludes to a passage in "On the Practice of the Mean" 中庸 that speaks to the all-encompassing nature of Heaven. 
8 夏戚與君并 佳人在遠道 妾身單且焭 歡會難再逢

12 芝蘭不重榮 人皆棄舊愛 君豈若平生 寄松為女蘿

16 依水如浮萍 褱身奉衿带 朝夕不墮傾 儻願終顧盼

20 永副我中情

4.25 閨情（其二）

有一美人

被服纖羅

妖姿艶麗

4 荨若春華

紅顔鞾曄

雲䯵嵯峨

彈琴撫節

8 爲我弦歌 
8 My cares and worries are the same as yours.

My good man is on a distant road,

While I am alone and unaided.

A happy reunion will be hard to chance on again -

12 Thoroughwort and angelica do not bloom twice.

Men always spurn old loves,

How could you remain as you used to be?

I was the lichen attached to the pine,

16 Like duckweed floating on water.

I devoted myself to you, attended to your collar and sash -

Morning and evening they did not sag or slant.

If you wish always to regard me fondly,

20 It will forever match my truest feelings.

\subsection{Boudoir Feelings, No. 2}

There is a beautiful woman,

Dressed in sheer gauze.

Her enchanting appearance and seductive beauty

4 As lush as springtime blossoms.

Her rosy face is radiant and striking,

And her cloud-like chignon juts upward.

She plucks the zither and beats the time,

8 Plays and sings for me. 
清濁齊均

既亮且和

取樂今日

12 遑恤其他

4.26 三良

功名不可為

忠義我所安

秦穆先下世

4 三臣皆自残

生時等榮樂

既沒同夏患

誰言捐軀易

8 殺身誠獨難

攬涕登君墓

臨穴仰天靯

長夜何冥冥

12 一往不復還

黄鳥為悲鳴

哀哉傷肺肝 
The clear and turbid sounds are balanced,

Are both bright and harmonious.

Enjoying myself on this day,

12 How can I worry about other things?

\subsection{Three Good Men}

"Merit and fame cannot be made,

Loyalty and duty are what content us."

Duke Mu of Qin departed the world first,

4 Then three subjects all slew themselves. ${ }^{1}$

While he lived, they were equal in glory and joy;

Once he died, they shared grief and suffering.

Who says sacrificing one's life is easy?

8 To kill oneself is truly hard.

Shedding tears, I ascend your tumulus,

Approaching the vault, look to Heaven and sigh.

That eternal night, how dark, dark!

12 Once gone, we never come back.

The yellow bird sadly calls for them,

Alas! It wounds my innermost heart.

1 This poem was inspired by an event that took place in 620 BCE. Duke Mu of Qin died that year, and, according to one account, one hundred seventy-seven people went to their deaths with him, including the Three Good Men, who committed suicide out of a sense of obligation. The Classic of Poetry poem (Mao shi 131) “Yellow Bird," or "Oriole" 黄鳥, is supposed to have been composed to mourn them. 


\subsection{7 責躬（有表）}

臣植言：臣自抱費歸蕃, 刻肌刻骨。追思 罪戻, 畫分而食, 夜分而寎。誠以天綱不 可重罹, 聖恩難可再恃。寀感相鼠之篇, 無禮遄死之義。形影相止, 五情愧郝。以 罪棄生, 則違古賢夕改之勸; 忍垢苟全, 則犯詩人胡顔之譏。伏惟陛下德象天地, 恩隆父母, 施暢春風, 澤如時雨。是以不 別荆棘者, 慶雲之惠也; 七子均養者, 隝 鳩之仁也; 舍罪責功者, 明君之舉也; 矜 愚愛能者, 慈父之恩也。是以愚臣徘䧃於 恩澤而不敢自棄者也。前奉詔書, 臣等絕 朝, 心離志絕, 自分黄若永無執圭之望。 不圖聖詔, 猥垂齒召。至止之日, 馳心杽 


\subsection{Blaming Myself (with memorial) ${ }^{1}$}

Your servant Zhi states:

From the time that I returned to my fief bearing my guilt, it has been engraved upon my flesh and bones. When I recall my crimes, it is noon before I can eat and midnight before I can sleep. I honestly realize that I cannot again run afoul of the laws of the state; it would hardly be possible to rely on your sage mercy again. Your subject is sensible of the poem "See the Rat" - the implication that one who lacks propriety should quickly die. ${ }^{2}$ My form and shadow commiserate with each other, and my five emotions blush with shame. If because of my crime, I forfeit my life, then I violate the injunction of the ancient worthy to "reform in the evening;" if I endure disgrace and somehow or other preserve my life, then I risk the poet's ridicule "What face!" ${ }^{3}$ In my humble opinion, Your Majesty's beneficence is like Heaven and Earth, Your kindness surpasses that of a father and mother; Your goodwill flows as freely as the spring wind; Your generosity is like timely rain. Therefore, not discriminating against thorns and brambles, such is favor of felicitous clouds; nurturing equally its seven chicks, such is the benevolence of the cuckoo; ${ }^{4}$ pardoning offenses and demanding performance, such is the behavior of an enlightened ruler; pitying ignorance and cherishing ability, such is the kindness of an affectionate father. Therefore, this ignorant servant is one who lingers on in your kindness and generosity and does not dare to give up on himself. Formerly, when

1 The memorial and poem, as well as poem 4.15, are addressed to Cao Pi, who was emperor of Wei. They were written in the fourth year of the Huangchu reign period (223).

2 This is an allusion to lines from a Classic of Poetry poem (Mao shi 52/3): "See the rat, it has limbs. / A man without propriety, / A man without propriety, / Why doesn't he hurry up and die” 相鼠有體, 人而無禮, 人而無禮, 胡不遄死.

3 Confucius' disciple Zengzi must be the "ancient worthy” Cao Zhi had in mind. Zengzi is reported to have said, "If someone errs in the morning but corrects it in the evening, then praise him; if someone errs in the evening but corrects it in the morning, then praise him." It is not as clear what might have been the source for the words "What face!"

4 This is an allusion to these lines from another Classic of Poetry poem: "The cuckoo in the mulberry / Has seven chicks." The commentary to these lines says that the cuckoo treats all of its chicks equally. 
轂。僻處西館, 未奉關庭。踊躍之懷, 瞻 望反側, 不勝犬馬戀主之情。謹拜表, 並 獻詩二首。詞旨浅末, 不足采覽, 貴露下 情, 冒顔以聞。臣植誠惶誠恐, 頓首頓 首, 死罪死罪。

於穆顯考

時惟武皇

受命于天

4 寧濟四方

朱旗所拂

九土披攘

玄化滂流

8 荒服來王

超商越周

與唐比蹤

篤生我皇

12 奕世載聰 
I received the edict that Your servant and the others were cut off from court, the heart went out of me and my will was broken. ${ }^{1}$ I thought that until I was old and gray I would have no hope of holding a scepter of office. I did not expect that an imperial edict would come down to appoint me to official rank. From the day I arrived and halted in the capital, my heart has sped toward Your Highness. I am residing isolated in the west mansion and have not yet attended court. With a leaping and throbbing heart, I peer out and toss and turn. I am unable to contain my feelings, which are like those of a dog or horse for its master. I respectfully submit this memorial and at the same time present two poems. The words and import are shallow and trivial, and they are not worth selecting and reading closely. But I value expressing my lowly feelings, and I will risk Your displeasure to make them known to you. Your servant Zhi is truly terrified, truly afraid. I knock my head on the ground, I knock my head on the ground. I deserve death, I deserve death.

$\mathrm{O}$, august our illustrious father, This was the Martial Emperor. ${ }^{2}$

He received the mandate from Heaven,

4 Pacified and assisted the four quarters.

Where his vermilion flags waved,

The nine lands were swept clear. ${ }^{3}$

His profound influence spread extensively,

8 The wild zones came to pay allegiance.

He surpassed Shang and exceeded Zhou, Matched Tang stride for stride. ${ }^{4}$ Blesséd born was our sovereign:

12 A sequent generation again astute. ${ }^{5}$

1 Cao Zhi is referring here in particular to his brothers Cao Zhang and Cao Biao, who were also sent away from court.

2 Cao Cao is the "illustrious father" and "Martial Emperor."

3 On the vermilion flags, see 1.1, line 11 .

4 Shang and Zhou are the dynasties by those names. Tang is the legendary ruler Yao.

5 Beginning with line 11, the poem shifts from praising Cao Cao to praising Cao $\mathrm{Pi}$. The sense of line 12 is that both Cao Cao and Cao Pi were intelligent. 
武則肅烈

文則時雍

受禪于漢

16 君臨萬邦

萬邦既化

率由舊則

廣命懿親

20 以藩王國

帝曰爾侯

君茲青土

奄有海濱

24 方周于魯

車服有輝

旗章有敘

濟濟售义

28 我崸我輔

伊予小子

恃寵䣖盈

舉挂時網

32 動亂國經 
In matters of war, he is solemn and intense;

In matters of culture, he is harmonious and concordant.

He received the abdication of the Han,

16 Governed as ruler the myriad states.

The myriad states having been transformed,

He follows the old rules.

He broadly ordered excellent kinsmen

20 To be a fence for his royal realm.

The Emperor said, "You, Marquis,

Rule this land of Qing,

Completely covering the ocean shore,

24 Just the way Zhou was to Lu."

My conveyances and clothing were resplendent,

My flags and ensigns had my rank.

Clustered were the virtuous and talented:

28 My aides and my assistants.

I, the little child,

Presumed on favor, was arrogant and complacent.

My behavior violated the ordinances of the time,

32 My actions disrupted the laws of the state. ${ }^{3}$

1 Qing refers to Qingzhou, in what is now northeastern Shandong. Its administrative seat was Linzi. Cao Zhi was appointed Marquis of Linzi in 214, but Cao Pi reappointed him and reassigned him to live there.

2 The Duke of Zhou, brother of the Zhou dynasty founder and himself one of the great icons of Chinese history, was the titular founder - a son of his was the actual founder - of the state of Lu. Like Qingzhou, Lu was in the Shandong region. Cao Zhi is drawing on the historical parallel offered by an important member of the Zhou ruling family having been installed in the Shandong region.

3 It is probable that lines 29-32 refer to an incident in 217 in which Cao Zhi got drunk and rode his carriage down the roadway that was reserved for the ruler's use and went out the Major's Gate, which was also reserved for the ruler. This greatly angered his father Cao Cao. 
作藩作屏

先軌是陏

傲我皇使

36 犯我朝儀

國有典刑

我削我黜

將置于理

40 元凶是率

明明天子

時惟篤類

不忍我刑

44 暴之朝肆

違彼執憲

哀予小子

改封竞邑

48 於河之濱

股忪井置

有君無臣

荒淫之關

52 誰弱予身 
I served as a fence, served as a screen,

But the former rules, those I destroyed.

I spurned my imperial envoy,

36 And violated my court etiquette.

The state has statutory punishments:

My benefice was reduced, I was demoted in rank.

I was about to be sent before the judge;

40 Major felon, thus was I classed.

The wise and perceptive Son of Heaven,

He was generous to his kind.

He could not bear my being punished,

44 To expose my corpse in court or market.

He went against those who enforce the laws,

Pitied me, the little child.

He changed my benefice to the seat of Yan,

48 On the banks of the Yellow River. ${ }^{1}$

Of trusted aides, none were provided;

I was a lord without officials.

With my fault of profligate excess,

52 Who was there to keep me straight?

1 Lines 29-56 deal with an incident in the second year of the Huangchu period that almost cost Cao Zhi his life. He got drunk and was insolent to the official who had been specifically assigned to watch him. Cao Zhi was sent to Luoyang, and seems only to have escaped death when his mother intervened with $\mathrm{Cao} \mathrm{Pi}$ to save his life. His enfeoffment was soon changed to Marquis of Juancheng, which was in Yan. See the "Introduction," p. xxiv. 
勞勞僕夫

于彼冀方

咩予小子

56 乃罹斯殊

赫赫天子

恩不遺物

冠我玄冕

60 要我朱紱

光光大使

我第我華

剖符授玉

64 王爵是加

仰齒金雪

俯執聖策

皇恩過隆

68 祇承忧惕

咨我小子

頑凶是嬰

逝悼陵墓

72 存愧關庭 
Alone and unaided,

I went to that land of Ji.

$\mathrm{O}, \mathrm{I}$, the little child,

56 Thus met this disaster. ${ }^{1}$

Illustrious and grand the Son of Heaven,

His kindness neglects no creature.

He capped me with a black official cap,

60 Placed vermilion ribbons about my waist.

Radiant was the great envoy,

I was granted honor, I was granted glory.

He split a tally, bestowed a jade;

64 The rank of prince, this was conferred.

Looking up, I accepted a metal seal;

Looking down, I held an imperial patent.

The sovereign's kindness was more than generous,

68 I received it respectfully, trembling with fear.

Ah, I, the little child,

Stubbornness and wickedness, these enmesh me.

To the departed, I am ashamed before his tumulus;

72 To the living, I am embarrassed before his court.

1 Lines 49-56 concern yet another time in the second year of Huangchu that Cao Zhi was in serious trouble. No record of this is found in his biography in the Records of the Three States, so the present memorial and poem, along with a command (ling 令) he wrote are the only sources. He was apparently accused by the officials Wang Ji and Cang Ji on specious charges and had to go to Luoyang again for adjudication. He was cleared and allowed to return to his benefice. 
匪敢傲德

實恩是恃

威霝改加

76 足以沒齒

昊天圈極

生命不圖

常懼顛泫

80 抱罪黄壚

願蒙矢石

建旗東嶽

庶立毫鳌

84 微功自贖

危軀授命

知足免戻

甘赴江湘

88 蒿戈吴越

天啟其衷

得會京畿

遲奉聖顔 
I dare not disdain Your beneficence,

For in truth I have relied on your kindness.

Your awesome sagacity has changed my fief and raised my rank,

76 And this will suffice till the end of my days.

Vast heaven has no bounds,

Human fate cannot be predicted.

I have always feared dropping dead,

80 And bearing my guilt to the yellow soil.

I wish to brave arrows and stones,

To plant our flag on the Eastern Peak.

I hope to establish some trifling merit,

84 The smallest deed to redeem myself.

I would endanger my body, offer up my life,

Content to have avoided punishment.

I would gladly go to the Jiang and Xiang,

88 Brandish a dagger-ax in Wu and Yue.

Heaven opened up Your innermost heart, And I have obtained an audience in the capital domain. I look forward to attending upon your sage countenance, 
92 如渴如飢 心之云慕 愴矣其悲 天高瑵卑

96 皇肯照微

\subsection{8 情詩}

微陰疑陽景

清風飄我衣

游魚潛綠水

4 翔鳥薄天飛

眇眇客行士

徭役不得歸

始出嚴霜結

8 今來白露晞

遊子嘆㯟離

處者歌式微

慷慨對嘉賓

12 悽愴內傷悲 
92 As though thirsting, as though starving.

How my heart yearns -

Despondent in its sadness.

Heaven is high yet hears the lowly,

96 The sovereign agrees to regard the humble.

\subsection{Love Poem}

A light overcast veils the sunlight,

A fresh breeze ruffles my clothes.

Swimming fish lie low in green water,

4 Soaring birds fly close to heaven.

Far, far away the wayfaring man;

On distant service, unable to return.

When first he left, severe frost had formed;

8 Now the white dew has dried.

The wanderer chants the poem "The Millet Hangs,"

The one at home sings the poem "No Use."

With brave forbearance I face my fine guests;

12 Heartsore and heartsick, inside I am grieved and sad.

1 These two lines refer to Shi jing poems. "The Millet Hangs" is the lament of a careworn person incessantly on the move. On "No Use," see 1.10. 


\subsection{9 妬}

嗟爾同食

曾不是志

寧彼冶容

4 安此妒忌

\subsection{0 芙蓉池}

逍遙芙蓉池

翩翩戲輕舟

南揚棲隻鵠

4 北柳有鳴鳵

\subsection{1 雜詩}

悠悠遠行客

去家千餘里

出亦無所之

4 入亦無所止

浮雲疑日光

悲風動地起 


\subsection{Jealousy (fragment)}

Ah, you shared a quilt with me, But you never remember this. Instead of those attractive looks,

4 Whence this jealousy and spite?

\subsection{Lotus Pond (fragment)}

Carefree at the Lotus Pond,

Skimming along, having fun on a light boat.

By a poplar to the south, a pair of roosting swans;

4 On a willow to the north there is a calling dove.

\subsection{Unclassified Poem}

On and on, the long-distance traveler, A thousand $l i$ and more from home.

When he leaves, he has nowhere to go;

4 When he comes, he has nowhere to stop.

Drifting clouds screen the sunlight,

Sad winds rise and shake the ground. 


\subsection{2 雜詩}

美玉生磐石

寶㓣出龍濎

帝王臨朝服

4 䓙此威百蠻

$\square \square$ 歷見貴 [歷久不見貴]

雜糅 $\square$ 刀閒 [雜糅刀劍間]

\subsection{3 言志}

慶雲未時興

雲龍潛作魚

神鸞失其儔

4 還從燕雀居 


\subsection{Unclassified Poem (fragment)}

Fine jade is born from slabs of stone, A precious sword comes from Dragon Pool. ${ }^{1}$

If an emperor or king wears it to court,

4 Grasping this will awe the hundred Man. ${ }^{2}$

For a long time it has not been valued, Is mixed among nondescript sabers and swords.

\subsection{Stating My Aims (fragment)}

Felicitous clouds have not arisen on time,

The cloudy dragon remains submerged feigning a fish. ${ }^{3}$

The divine simurgh has lost its kind,

4 And instead dwells with swallows and sparrows.

1 Dragon Pool is a place name here, but it was also the name of a famous sword in antiquity. It appears as such in Cao Zhi's famous "Letter to Yang Dezu" 與楊德祖書, and it also appears in earlier texts. The place known as Dragon Pool, or Dragon Springs 龍泉, in Xiping 西平 of Runan 汝南 had water that was good for tempering sabers and swords to make them hard and sharp.

2 "Hundred Man" is a term applied to non-Chinese peoples of the south.

3 Dragons were said to ride on clouds, and a submerged, or hidden, dragon became a metaphor for the worthy man whose talents were not being used in government. 


\subsection{4 七步詩}

煮豆燃豆萁

漉豉以為汁

本是同根生

4 相煎何太急

\subsection{5 離別詩}

人遠精神近 嶈䨽萝容光

\subsection{6 失題}

隻鶴俱邀游 相失東海傍

雄飛竄北朔

4 此驚赴南湘 棄我交頸歡 離別各異方 不惜萬里道 8 但恐天網張 


\subsection{Poem in Seven Paces}

Boil beans by burning beanstalks,

Strain fermented beans to make a juice.

Beanstalks burn beneath the pot,

4 Beans in the pot weep,

We are born from the same root,

Why such hurry us to fry? ${ }^{1}$

\subsection{Parting (fragment)}

The man is far away but his spirit is near,

Awake or asleep, I dream of the radiance of his face.

\subsection{Title Lost}

A pair of cranes roamed together, They lost each other by the eastern sea.

The male flew off and hid in the boreal north,

4 The female was frightened and hastened to the southern Xiang.

Forsaking our pleasure from crossing necks,

We part, each in a different direction.

I do not begrudge the myriad $l i$ road,

8 I only fear the spreading of the heavenly net. ${ }^{2}$

1 This poem is not authentic. Its first appearance is in A New Account of Tales of the World 世說新語, a work of the fifth century, where it is embedded in this anecdote: "Emperor Wen [Cao Pi] once ordered the King of Dong'e [Cao Pi] to compose a poem in the time it took to walk seven paces. Should he not complete it, the death penalty would be carried out. Immediately in response, he composed this poem [the poem quoted at this point differs slightly from the one above]. The emperor had a profoundly embarrassed expression."

2 "Heavenly net" may be understood to refer to the authority of the royal court. 